\title{
BRPKM
}

Buletin Riset Psikologi dan Kesehatan Mental

http://e-journal.unair.ac.id/index.php/BRPKM

e-ISSN: 2776-1851

ARTIKEL PENELITIAN

\section{Pengaruh Kontrol Diri terhadap Perilaku Seksual pada Remaja Berpacaran}

\author{
SASMITA PALUPI RIZKYANI PUTRI \& ATIKA DIAN ARIANA* \\ Fakultas Psikologi Universitas Airlangga
}

\begin{abstract}
ABSTRAK
Perilaku seksual merupakan salah satu proses tahapan perkembangan yang dialami remaja. Namun, banyak remaja bahkan bereaksi terhadap sikap dan perilaku yang tidak wajar dan tidak bermoral. Tetapi, di Indonesia, perilaku seksual ini menyimpang ketika dilakukan terhadap remaja dan pasangan yang belum menikah. Perilaku menyimpang dipengaruhi oleh kondisi lingkungan dan sulitnya mengontrol diri pada masa remaja. Penelitian ini bertujuan untuk mengetahui pengaruh antara kontrol diri terhadap perilaku seksual pada remaja berpacaran di Surabaya. Penelitian kuantitatif ini menggunakan metode survei dengan melibatkan 86 remaja. Penelitian ini menggunakan alat ukur kontrol diri dan perilaku seksual. Hasil penelitian ini menunjukkan bahwa kontrol diri memiliki pengaruh yang positif dan signifikan terhadap perilaku seksual pada remaja berpacaran di Surabaya.
\end{abstract}

Kata kunci: kontrol diri, remaja berpacaran

\section{ABSTRACT}

Sexual behavior is one of the stages of development experienced by adolescents. However, many teenagers even react to unnatural and immoral attitudes and behaviors. However, in Indonesia, this sexual behavior is deviant when it is carried out against adolescents and unmarried couples. Deviant behavior is influenced by environmental conditions and the difficulty of self-control in adolescence. This study aims to determine the effect of self-control on sexual behavior in adolescent dating in Surabaya. This quantitative study used a survey method involving 86 adolescents. This study uses a measuring instrument of self-control and sexual behavior. The results of this study indicate that self-control has a positive and significant influence on sexual behavior in adolescent dating in Surabaya.

\section{Keywords: adolescent dating, self-control}

Buletin Penelitian Psikologi dan Kesehatan Mental (BRPKM), 2021, Vol. 1(2), 1275-1281

*Alamat korespondensi: Fakultas Psikologi Universitas Airlangga, Kampus B Universitas Airlangga Jalan Airlangga 4-6 Surabaya 60286. Surel: atika.ariana@psikologi.unair.ac.id

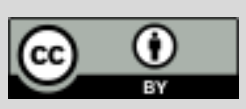

Naskah ini merupakan naskah dengan akses terbuka dibawah ketentuan the Creative Common Attribution License (CC-BY-4.0) (http://creativecommons.org/licenses/by/4.0), sehingga penggunaan, distribusi, reproduksi dalam media apapun atas artikel ini tidak dibatasi, selama sumber aslinya disitir dengan baik. 


\section{PEN D A H U L U A N}

Perkembangan individu melalui beberapa tahap dan salah satu tahapan yang dilalui individu adalah masa remaja. Santrock (2007) mendefinisikan masa remaja sebagai periode perkembangan sementara antara masa anak-anak dan dewasa, yang meliputi perubahan biologis, kognitif, dan sosial-emosional. Masa remaja dibagi menjadi masa remaja awal, yaitu berusia 12 sampai 15 tahun, remaja pertengahan berusia 16 sampai 18 tahun, dan remaja akhir berusia 19 sampai 21 tahun (Monks dkk., 2006)

Organisasi Kesehatan Dunia menyatakan bahwa sekitar seperlima populasi dunia terdiri dari remaja berusia antara 10 hingga 19 tahun dan sekitar 900 juta tinggal di negara berkembang. Menurut demografi AS, usia 10 hingga 19 tahun membentuk sekitar 15\% dari populasi. Di sisi lain, penduduk kawasan Asia-Pasifik dengan jumlah penduduk dunia sebesar 60\% berusia 10-19 tahun yang merupakan seperlima dari total penduduk wilayah tersebut. Berdasarkan data Badan Pusat Statistik (2020), jumlah penduduk Indonesia sebanyak 270,2 juta jiwa, 74,9 juta jiwa di antaranya adalah remaja. Jumlah penduduk mencapai 2,87 juta jiwa dengan komposisi penduduk sebesar $25,79 \%$ merupakan usia remaja.

Remaja merupakan individu yang sedang berada dalam proses perkembangan, yaitu dalam proses pendewasaan atau kemandirian. Proses perkembangan itu tidak selalu terjadi secara linier atau sejalan dengan kemampuan, harapan dan nilai-nilai yang dijunjung, karena banyak faktor yang menghambatnya. Hambatan ini bisa bersifat internal maupun eksternal. Pada situasi tersebut, kebanyakan remaja menanggapi sikap dan perilaku yang tidak pantas dan tidak bermoral, seperti perkelahian, penggunaan narkoba, tindakan kriminal, dan perilaku seksual beresiko (Sari, 2014).

Survei Kesehatan Reproduksi Remaja (SKRR), yang dikutip dalam sebuah studi kasus (Israwati dkk., 2018), menunjukkan bahwa remaja Indonesia mulai berpacaran ketika mereka berusia 12 tahun. Menurut Muus (dalam Ekasari, 2009), pacaran dapat mempelajari aturan sosial baru untuk memahami bagaimana menerima pasangan seksual seseorang atau diri sendiri. Muus menyatakan bahwa kebanyakan remaja mengira berpacaran hanya untuk bersenang-senang bagi remaja yang berpacaran tanpa komitmen. Padahal berpacaran seharusnya dijadikan sebagai proses pembelajaran bagi individu untuk mempelajari serta memahami kebiasaan, kepribadian,dan perasaan orang lain. Tetapi, pacaran baru-baru ini digunakan sebagai sarana diskriminasi terhadap hasrat seksual, selain adanya proses berkenalan anatara pasangan, ada juga riwayat aktivitas seksual (Alfiani \& Suharso, 2013).

Munculnya hasrat dan kasih sayang seksual mendorong remaja untuk lebih sering intim dan menginginkan kontak fisik bersama pacarnya. Keintiman fisik dan kontak fisik yang terjadi antara remaja yang berpacaran berbeda dengan keintiman fisik dan kontak fisik antara remaja dengan teman atau anggota keluarga. Selama pacaran, hal tersebut yang pada akhirnya mengarah pada perilaku seksual (Rahman \& Hirmaningsih, dalam Mayasari \& Hadjam, 2000).

Perilaku seksual, baik heteroseksual maupun homoseksual, adalah perilaku yang dimotivasi oleh hasrat seksual. Perilaku seksual remaja dimanifestasi dalam berbagai perilaku, antara lain, berpegangan tangan (termasuk menggenggam dan bergandeng tangan), berpelukan (termasuk memeluk dan merangkul), berciuman (termasuk berciuman pipi dan bibir), meraba atau memegang bagian sensitif (seperti payudara, vagina dan penis), petting (menggesek-gesekkan bagian tubuh yang sensitif kepada pasangan seperti payudara dan alat kelamin), dan melakukan senggama atau intercourse (aktivitas seksual dengan memasukkan alat kelamin laki-laki ke dalam alat kelamin perempuan) (Sarwono, 2012).

Menurut hasil Survei Kesehatan Reproduksi Remaja Indonesia (2012, dalam Ashari dkk., 2019), remaja laki-laki dan perempuan pernah menyentuh dan merangsang pasangannya, menciuman bibir dan memegang tangan pasangannya. Menurut survei yang dilakukan Sari (2014) tentang pola perilaku 
berpacaran pada remaja di SMA Surabaya, remaja saling berpegangan tangan, berpelukan, pernah berciuman, menyentuh bagian sensitif satu sama lain dengan pasangannya, petting, serta oral seks, dan remaja mengklaim sudah pernah berhubungan intim dengan pasangan.

Data dari Departemen Kesehatan RI (2007) menemukan bahwa 11,1\% remaja Surabaya pernah pernah berhubungan seksual, namun 66\% responden mengaku memiliki teman, sehingga aspek ini tetap harus diwaspadai. Berdasarkan hasil survei Sya'diyah \& Duryati (2019) terhadap 20 remaja menunjukkan banyak faktor yang menjadi alasan remaja melakukan aktivitas seksual termasuk frekuensi mengakses situs porno yang paling banyak dikunjungi. Alasan kedua adalah remaja tidak memiliki kendali atas seksualitasnya karena dorongan seksual yang dirasakan. Alasan ketiga adalah mengikuti teman yang bercerita jika pernah berhubungan seksual dengan pasangannya. Terakhir yaitu kurangnya nilai-nilai agama yang ditanamkan orang tua pada masa remaja.

Remaja cenderung berperilaku menyimpang karena pengaruh lingkungan dan remaja sulit mengendalikan diri (Santrock, 2012 dalam Sya'diyah \& Duryati, 2019). Dapat dikatakan bahwa remaja sendiri kurang memiliki pengendalian diri, baik karena kegagalan sistem pengendalian diri dalam menghadapi pengaruh eksternal dan dorongan internal yang kuat, maupun dalam menghadapi rangsangan di sekitarnya. Oleh karena itu, terlibat dalam perilaku menyimpang, ia menganggap perilaku yang termasuk "nilai lebih" dari individu maupun teman sebaya yang mendorongnya. Hal ini menunjukkan bahwa adanya pengaruh antara kontrol diri dan perilaku seksual yang mempengaruhi pengambilan keputusan remaja mengenai perilaku seksual (Dewi, 2014). Mengontrol diri dapat diartikan sebagai mengatur setiap tindakan yang dilakukan oleh remaja. Bagaimana remaja dapat menentukan semua tindakan yang mereka dan orang lain lakukan terhadap diri mereka sendiri, termasuk perilaku seksual pasangannya.

Lazarus (1973, dalam Thalib, 2017) menyatakan kontrol diri menggambarkan keputusan individu melalui serangkaian pertimbangan kognitif dalam mengendalikan perilaku untuk meningkatkan hasil dan mencapai tujuan. Kontrol diri adalah kemampuan seseorang dalam membaca kondisi lingkungan, mengontrol dan mengelola faktor perilaku serta beradaptasi dengan orang lain untuk menutupi perasaannya (Ghufron \& Risnawati, 2014).

Keterkaitan antara kontrol diri dengan perilaku remaja berpacaran menunjukkan bahwa pengendalian diri remaja memegang peranan penting dalam mencegah perilaku seksual. Banyaknya aktivitas yang dilakukan selama masa remaja merupakan faktor yang dapat mengurangi terjadinya segala bentuk perilaku seksual. Adanya pengendalian diri memungkinkan seorang remaja untuk menekan rangsangan negatif seperti perilaku seksual baik secara internal maupun eksternal. Hal ini didukung oleh penelitian yang menujukkan hubungan yang signifikan antara kontrol diri dengan perilaku seksual, sehingga semakin tinggi kontrol diri maka semakin rendah pula perilaku seksualnya, dan sebaliknya (Istiqomah \& Notobroto, 2017; Khairunnisa, 2013; Noor, 2018).

Dorongan dari perkembangan seksual mendorong remaja untuk mewujudkan dalam perilaku berpacaran yang melampaui batas norma yang ada dalam masyarakat. Bagi remaja di negara-negara Barat hal ini mungkin bukan sesuatu hal yang tabu. Namun di Indonesia, perilaku ini menyimpang jika dilakukan oleh remaja dan pasangan yang belum menikah. Oleh karena itu, remaja yang dapat mengontrol diri cenderung tidak melanggar hal-hal tabu seperti berciuman atau tindakan seksual lainnya. Keberhasilan penelitian ini nantinya dapat digunakan secara teoritis maupun praktis. Berdasarkan kajian literatur yang telah dijelaskan sebelumnya, hipotesis penelitian ini adalah kontrol diri memiliki pengaruh terhadap perilaku seksual pada remaja berpacaran di Surabaya. Adapun tujuan dari penelitian ini adalah untuk mengetahui apakah ada pengaruh antara kontrol diri terhadap perilaku seksual pada remaja berpacaran di Surabaya. 


\section{Desain Penelitian}

\section{E T O D E}

Penelitian ini merupakan tipe penelitian kuantitatif yang umumnya menggunakan teknik pengambilan sampel secara acak, menggunakan instrumen penelitian, dan analisis datanya menggunakan metode statistik. Pemilihan tipe penelitian kuantitatif ini didasarkan pada tujuan penelitian yakni untuk menguji hipotesis dengan cara memperoleh nilai signifikansi pengaruh antar variabel. Desain penelitian kuantitatif ini menggunakan metode survei untuk mengkaji populasi yang besar, dikarenakan metode survei dapat mengkaji populasi untuk dapat membuat generalisasi terkait karakteristik pada populasi tersebut.

\section{Partisipan}

Partisipan dalam penelitian ini merupakan remaja yang tersebar di seluruh wilayah Surabaya $(N=$ $86,6 \%$ perempuan, 31,4\% laki-laki). Penentuan sampel penelitian ini menggunakan teknik sampling non-probability dimana pemilihan sampelnya tidak memiliki data atau pengetahuan tentang seberapa besar populasi yang harus diteliti sesuai tujuan penelitian. Adapun kriteria partisipan dalam penelitian ini terdiri dari: a) remaja yang sedang berpacaran; b) usia 12-21 tahun; dan c) tinggal di Surabaya. Adapun proses pengumpulan data dilakukan secara online melalui Google form.

\section{Pengukuran}

Kontrol diri didefinisikan sebagai suatu variabel psikologis yang meliputi kemampuan untuk mengelola informasi yang diinginkan dan tidak diinginkan, kemampuan individu untuk memilih salah satu tindakan berdasarkan sesuatu yang diyakini sesuai norma yang berlaku dalam masyarakat serta kemampuan individu memodifikasi perilakunya (Averill, 1973 dalam Ghufron \& Risnawati, 2014). Intrumen yang digunakan untuk mengukur kontrol diri adalah skala yang diadaptasi oleh Ghufron \& Risnawati (2014). Skala ini memiliki 40 aitem yang disusun berdasarkan aspek kontrol perilaku (behavior control), kontrol kognitif (cognitive control), dan mengontrol keputusan (decision control), setiap aitem dinilai pada skala 4 (1="sangat sesuai", 2="sesuai", 3="kurang sesuai", 4="tidak sesuai"). Skala ini juga telah dilakukan uji reliabilitas dengan teknik Cronbach's alpha dan didapatkan nilai reliabilitas $\alpha=0,715$.

Perilaku seksual, baik heteroseksual maupun homoseksual, adalah perilaku yang dimotivasi oleh hasrat seksual (Sarwono, 2012). Intrumen yang digunakan untuk mengukur perilaku seksual adalah skala yang dibuat oleh peneliti sendiri berdasarkan aspek perilaku seksual yang dikemukakan oleh Sarwono (2012) yaitu berpegangan tangan, berpelukan, berciuman, meraba atau memegang bagian sensitif, petting, dan melakukan senggama atau intercourse. Skala ini terdiri dari 44 aitem di mana 28 aitem merupakan aitem favorable (menggambarkan perilaku seksual) dan 16 aitem lainnya merupakan aitem unfavorable (tidak menggambarkan perilaku seksual). Setiap aitem dinilai pada skala 4 (1="sangat sesuai", 2="sesuai", 3="kurang sesuai", 4="tidak sesuai") dan nilai skala ini dikonversi terbalik pada aitem unfavorable. Semua aitem dinilai valid pada penilaian rater expert judgement serta dilakukan uji reliabilitas dengan teknik Cronbach's alpha dan didapatkan nilai reliabilitas $\alpha=0,862$.

\section{Analisis Data}

Teknik analisis data yang digunakan untuk menguji hipotesis penelitian ini adalah teknik regresi sederhana yang telah memenuhi uji asumsi (normalitas, linearitas, multikolinearitas, dan heteroskedasitas). Perangkat lunak yang digunakan untuk menganalisa data penelitian ini adalah SPSS 25 for Windows. 


\section{HAS IL P EN ELIT IAN}

Hasil analisis deskriptif menunjukkan bahwa jumlah partisipan dalam penelitian ini sebanyak 86 partisipan dengan 27 partisipan laki-laki $(31,4 \%)$ dan 59 partisipan perempuan $(86,6 \%)$. Dari pengolahan data tersebut, diperoleh data tiap variabel yakni variabel kontrol diri $(M=100,46$; $\operatorname{Min}=87$; Max=100,46; $r=27)$ dan variabel perilaku seksual $(M=122,96 ; \operatorname{Min}=91 ; \operatorname{Max}=153 ; r=62)$.

Hasil analisis uji normalitas Kolmogrov-Smirnov menunjukkan bahwa kedua variabel berdistribusi normal $(p=0,200>0,05)$. Hasil analisis uji linearitas menunjukkan bahwa nilai signifikansi antara variabel kontrol diri dengan variabel perilaku seksual $(p=0,113)$ memiliki hubungan yang linier.

Berdasarkan hasil analisis uji regresi linier sederhana terdapat pengaruh yang signifikan antara kontrol diri dengan perilaku seksual ( $\mathrm{p}=0,000)$. Hasil analisis menunjukkan bahwa $(F(1,86)=14,395 ; B=0,740)$ maka semakin tinggi kontrol diri semakin rendah perilaku seksual.

\section{I S K U S I}

Hasil analisis penelitian ini menujukkan adanya pengaruh yang signifikan antara kontrol diri terhadap perilaku seksual pada remaja berpacaran di Surabaya. Selain itu, kontrol diri juga memiliki arah pengaruh yang positif terhadap perilaku seksual dimana semakin tinggi kontrol diri maka semakin rendah pula perilaku seksual begitupun sebaliknya semakin rendah kontrol diri maka semakin tinggi perilaku seksualnya. Hasil penelitian ini sejalan dengan temuan sebelumnya yang dilakukan pada subjek usia remaja antara usia 15 sampai 25 tahun yang menunjukkan adanya hubungan negatif antara kontrol diri pada mahasiswa dengan perilaku seksual. Dapat diartikan jika seseorang memiliki kontrol diri yang tinggi, maka perilaku seksualnya semakin kecil kemungkinannya dan sebaliknya (Dewi, 2014; Khairunnisa, 2013; Noor, 2018).

Penelitian Mahfiana dkk. (2009) menjelaskan bahwa kurangnya pengendalian diri pada masa remaja merupakan salah satu penyebab maraknya perilaku seksual yang menyimpang dari norma agama. Pertama, dengan menjaliin hubungan (pacaran) dengan lawan jenis, flirting dimulai dengan berpengangan tangan, yang mengarah pada aktivitas seksual lebih lanjut.

Sarwono (2012) menemukan bahwa remaja yang mengatur diri sendirilebih aktif secara seksual daripada remaja yang rentan atau situasinya ditentukan oleh faktor eksternal. Jika remaja berhasil menahan diri mereka cenderung tidak melakukan hal-hal tabu seperti flirting dan aktivitas seksual lainnya. Mengontrol diri berarti melakukan pengendalian secara internal yang memungkinkan untuk mengontrol tindakan dirinya.

Kauma (2003, dalam Arlyanti, 2012) menjelaskan bahwa salah satu penyebab perilaku seksual adalah diri remaja, khususnya kurangnya kemampuan untuk mengontrol dan mengendalikan diri. Hal ini sering membuat remaja melakukan hal-hal negatif, seperti melakukan hubungan seksual tanpa memikirkan konsekuensi dan risiko yang ditimbulkannya. Kartono (2002, dalam Arlyanti, 2012) juga menyatakan bahwa remaja pada umumnya kurang memiliki kontrol diri, karena tidak kuatnya menahan diri. Remaja cenderung mengungkapkan segala keinginannya dengan cara yang berbeda-beda tanpa mempertimbangkan apakah perilakunya menyimpang atau merugikan diri sendiri atau masyarakat.

Hurlock (2002, dalam Arlyanti, 2012) menjelaskan bahwa adanya pengendalian diri dipengaruhi oleh faktor internal dan eksternal. Faktor internal adalah faktor dari individu, seperti pengetahuan, usia, emosi, dan kepribadian. Faktor eksternal adalah lingkungan. Hal ini berarti bahwa individu harus mendapatkan apa yang mereka inginkan. Oleh karena itu, individu harus mengatur diri sendiri atau 
memiliki pengendalian diri yang baik agar tidak melanggar peraturan yang berjalan atau mengganggu kenyamanan lingkungan. Ketika seorang individu menjalani ini, teman sebaya atau masyarakat akan menghargai dan menerima apa yang menjadi milik individu tersebut.

\section{S I M P U L A N}

Berdasarkan hasil penelitian ini disimpulkan bahwa terdapat pengaruh yang signifikan antara variabel kontrol diri terhadap perilaku seksual pada remaja yang berpacaran di Surabaya. Arah pengaruh kontrol diri terhadap perilaku seksual menunjukkan arah yang positif. Hal ini menunjukkan bahwa semakin tinggi kontrol diri maka semakin rendah perilaku seksualnya, dan sebaliknya semakin rendah kontrol diri maka semakin tinggi perilaku seksual tersebut.

Penulis menyadari bahwa penelitian ini tentunya memiliki keterbatasan. Oleh karena itu penulis memberikan beberapa saran diantaranya untuk penelitian berikutnya untuk menghindari penggunaan kuesioner online agar dapat memastikan bahwa responden yang didapat sesuai kriteria sehingga mampu memantau saat pengisian kuesioner tersebut. Penelitian berikutnya juga dapat mengontrol terkait aspek etika mengingat terdapat variabel penelitian yang sensitif serta lebih memperhatikan fenomena awal yang sedang terjadi sehingga lebih kaya akan referensi yang bisa digunakan untuk membantu penelitian. Selain itu, penulis juga menyarankan agar remaja dapat menegnali perilaku seksual, melindungi diri dari perilaku seksual, dan meningkatkan kontrol diri dalam segala aspek kehidupannya untuk menghindari perilaku negatif yang dapat memberikan dampak yang buruk untuk diri sendiri dan oranglain. Penulis juga mengajukan saran kepada remaja berpacaran untuk perlu menetapkan tujuan berpacaran agar gejala aktivitas yang dilakukan mempunyai arah yang jelas dan tetap mengindahkan aturan yang diberlaku di masyarakat sehingga hal tersebut dapat membantu remaja terhindar dari hal-hal yang tidak diinginkan.

\section{U C A P A N T ERIMAKASIH}

Penulis mengucapkan terima kasih kepada Tuhan Yang Maha Esa atas segala nikmat dan rahmat yang telah dilimpahkan kepada penulis, kepada dosen pembimbing penulis Atika Dian Ariana S.Psi., M.Sc., kepada orang tua penulis, serta kepada remaja di Surabaya yang sudah bersedia menjadi partisipan dalam penelitian ini.

\section{DEKLARASI POTENSI TERJADINYAKONFLIK KEPENTINGAN}

Sasmita Palupi Rizkyani Putri dan Atika Dian Ariana tidak bekerja, menjadi konsultan, memiliki saham, atau menerima dana dari perusahaan atau organisasi manapun yang mungkin akan mengambil untung dari diterbitkannya naskah ini.

\section{PUSTAKA ACUAN}

Alfiani, D. A., \& Suharso, S. S. (2013). Perilaku Seksual dan Faktor Determinannya di SMA Se-Kota Semarang. Indonesian Journal of Guidance and Counseling, 2(4).

Arlyanti, R. (2012). Hubungan antara Kontrol Diri Dengan Sikap Terhadap Perilaku Seksual Pada Remaja Karang Taruna. Naskah Publikasi Fakultas Psikologi Univesitas Muhammadiyah Surakarta. 
Ashari, A., Hidayah, F. N., \& Rahmatika, S. D. (2019). Pengaruh Pengetahuan Kesehatan Reproduksi Terhadap Perilaku Seksual Remaja Berisiko Di Kota Cirebon. Prosiding Seminar Nasional LPPM UMP 2019.

Badan Pusat Statistik. (2020). Proyeksi Penduduk Kota Surabaya Menurut Jenis Kelamin dan Kelompok Umur. https://surabayakota.bps.go.id/

Departemen Kesehatan RI. (2007). Survei Terpadu Biologi dan Perilaku.

Dewi, A. K. (2014). Hubungan Kontrol Diri Dengan Perilaku Seksual Pranikah Pada Mahasiswa Universitas Negeri Semarang. Journal Psychology Universitas Negeri Semarang, 3(1).

Ekasari, D. (2009). Hubungan Antara Tingkat Penalaran Moral Dengan Sikap Remaja Terhadap Perilaku Seksual Pranikah Pada Siswa Kelas XI SMA PGRI 1 Pemalang. Skripsi: UNNES.

Ghufron, M. N., \& Risnawati, R. (2014). Teori-Teori Psikologi. Ar-Ruzz media.

Israwati, Rachman, W. A., \& Ibnu, I. (2018). Perilaku Seks Pra-Pranikah Mahasiswa pada Sekolah Tinggi Manajemen Informatika dan Komputer Bina Bangsa Kendari. (Studi Kasus). UNHAS, 53(9).

Istiqomah, N., \& Notobroto, H. B. (2017). Pengaruh Pengetahuan, Kontrol Diri terhadap Perilaku Seksual Pranikah di Kalangan Remaja SMK di Surabaya. Jurnal Biometrika dan Kependudukan, 5(2). https://doi.org/10.20473/jbk.v5i2.2016.125-134

Khairunnisa, A. (2013). Hubungan religiusitas dan kontrol diri dengan perilaku seksual pranikah MAN 1 samarinda. Psikoborneo, 1(3).

Mahfiana, L., \& Rochmah, E. Y., Widyaningrum, R. (2009). Remaja dan Kesehatan Reproduksi. STAIN Ponorogo Press.

Mayasari, F., Hadjam, M. N. R. (2000). Perilaku Seksual Remaja Dalam Berpacaran Ditinjau Dari Harga Diri Berdasarkan Jenis Kelamin. Jurnal Psikologi, 2.

Monks, F., Knoers, A., \& Hadinoto, S. (2006). Psikologi Perkembangan dalam Berbagai Bagiannya, Edisi Keempat Belas. Gadjah Mada University Press.

Noor, R. (2018). HUBUNGAN ANTARA KONTROL DIRI DENGAN PERILAKU SEKSUAL REMAJA PADA SISWA SMK ISTIQOMAH MUHAMMADIYAH 4 SAMARINDA. MOTIVA JURNAL PSIKOLOGI, 1(1). https://doi.org/10.31293/mv.v1i1.3491

Santrock, J. (2007). Remaja: Jilid 1. Erlangga.

Sari, R. T. (2014). Perilaku Seksual Remaja Siswa SMK Ketintang Surabaya. Jurnal BK, 4(3).

Sarwono, S. W. (2012). Psikologi Remaja (Edisi Revisi ed.). Rajawali Pers.

Sya'diyah, H., \& Duryati, D. (2019). Hubungan antara kontrol diri dengan perilaku seksual pada remaja di kota pariaman. Rap Unp, 2019(4).

Thalib, S. (2017). Psikologi Pendidikan Berbasis Analisis Empiris Aplikatif. Kencana.

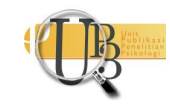

